\title{
REVISION OF THE LATE BASHKIRIAN CORDAITALEAN CORDAITES KARVINENSIS AND ALLIED DISPERSED CUTICLES FROM UPPER SILESIA, THE CZECH REPUBLIC
}

\author{
ZBYNĚK ŠIMŮNEK
}

Czech Geological Survey, Klárov 3/131, 11821 Praha 1, the Czech Republic; e-mail: zbynek.simunek@geology.cz.

Šimůnek, Z. (2019): Revision of the late Bashkirian cordaitalean Cordaites karvinensis and allied dispersed cuticles from Upper Silesia, the Czech Republic. - Fossil Imprint, 75(2): 258-267, Praha. ISSN 2533-4050 (print), ISSN 2533-4069 (on-line).

\begin{abstract}
The Langsettian species Cordaites karvinensis S̆IMŮNEK and C. sustae ŠIMŮNEK were found conspecific, with C. karvinensis chosen as a correct name. These species come from the same coal seam of the Upper Suchá Member (Upper Silesian Basin, the Czech Republic). Abaxial cuticle from C. karvinensis was found conspicuously similar to Cordaabaxicutis cf.jaworznoensis from the Lower Suchá Member from the strata near the Namurian/Westphalian boundary, as well as to Cordaabaxicutis jaworznoensis ŠIMŮNEK et FLORJAN described from the Orzesze Beds (Duckmantian) from Poland. The abaxial cuticles of all these species are papillate. It is probable that these species are members of one evolutionary lineage, however without information on the leaf morphology connected to the dispersed cuticles of Cordaabaxicutis, this opinion remains hypothetical.
\end{abstract}

Key words: Cordaites, Upper Silesian Basin, cuticular analysis, Karviná Formation, Pennsylvanian, Bashkirian

Received: January 15, 2019 | Accepted: March 13, 2019 | Issued: November 25, 2019

\section{Introduction}

During study of the dispersed cuticles from the Upper Silesian Basin, it was necessary to compare them with "in situ" cordaitalean cuticles published by Šimůnek (2007). Three Cordaites species from this locality have been described based on the cuticles. The cuticles were prepared from samples collected by V. Šusta and determined on labels as Cordaites borassifolius (one specimen) and Cordaites principalis (two specimens). Based on the cuticles, these species were described as Cordaites karvinensis, C. sustae and $C$. silesiacus (Šimůnek 2007). However, similar cuticles to $C$. sustae have been found in dispersed cuticular spectra (Šimůnek and Florjan 2013a, b, Šimůnek 2019).

The species Cordaites karvinensis and C. sustae, originally determined on labels by V. Šusta as Cordaites principalis, have similar leaf shape and similar venation. Revision of cuticules of both species shows that their differences are maybe caused only by different preservation. Cuticles of Cordites karvinensis are poorly preserved and therefore appeared different from Cordaites sustae. In this paper, comparison of the external morphology of leaves of both species and also their cuticles is presented. It seems that both species belong to one biological species that should be named Cordites karvinensis.

\section{Material and methods}

The fossil leaves originally determined by Šusta (on labels) as Cordaites principalis (GERMAR) GEINITZ are housed in the Ostrava Museum collection. Sample A 5999 was subsequently described as the holotype of Cordaites karvinensis S̆IMƯNEK and sample A 6581 was described as the holotype of $C$. sustae ŠIMƯNEK (Šimůnek 2007). Both holotypes come from the roof of the $19^{\text {th }}$ coal seam of the Hlubina (Depth) Mine in Karviná (Text-fig. 1). The age is Langsettian, Karviná Formation, Upper Suchá Member.

Dispersed cuticles described in the present paper were obtained from a coal sample taken from the borehole K-65/17, ČSA Mine, Karviná locality, depth 5.1 m, Lower

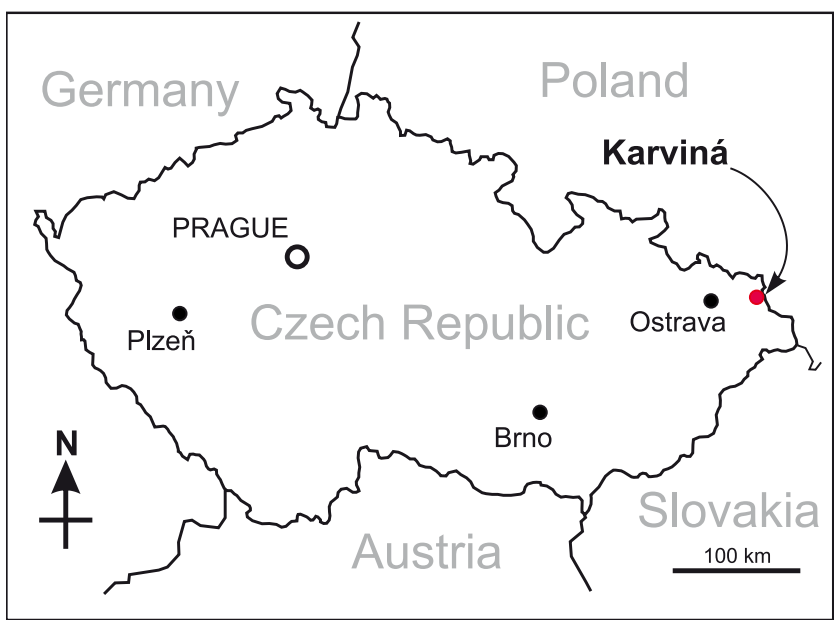

Text-fig. 1. Chart of the Czech Republic with the locality Karviná. 
Table 1. Comparison of stratigraphy in the Czech and Polish parts of the Upper Silesian Basin (Dopita et al. 1997, Cleal et al. 2009). * - only locally developed; ** - numbers in brackets used in coal mines; UD - "Upper Doubrava coal seams"; $\uparrow$ - in situ cuticles from Cordaites; $*$ - dispersed cordaitalean cuticles.



Suchá Memeber, coal seam 26 (680), near the Namurian/ Westphalian boundary.

The coalified cordaitalean leaf fragments were separated from the encompassing rock by hydrofluoric acid (HF). Cuticles were prepared according to the method described by Kerp (1990). Leaf fragments were bleached in Schulze reagent (conc. $\mathrm{HNO}_{3}$ with crystals of $\mathrm{KClO}_{3}$ ). Maceration time was about 6 hours. After treatment in Schulze reagent, the cuticles were washed and rinsed in water. The cuticles were dehydrated in pure glycerine before being embedding in glycerine gelatine slides.

The coal sample was macerated in a similar way. $5 \mathrm{~g}$ of coal were treated in $35 \mathrm{~mm}$ of conc. nitric acid $\left(\mathrm{HNO}_{3}\right)$ with $2 \mathrm{~g}$ potassium chlorate $\left(\mathrm{KCHO}_{3}\right)$. Maceration time was more than 3 days. The macerated coal was then thoroughly rinsed in water and treated in $10 \%$ potassium hydroxide $(\mathrm{KOH})$ and again rinsed in water. The remaining substance after cuticle separation was used for obtaining palynomorphs and megaspores. The cuticles were mounted on glycerine gelatine slides or affixed to a stub for observation under a scanning electron microscope.

\section{Geological setting}

The late Palaeozoic Upper Silesian Basin was formed as part of the European Variscan fold belt and extends over an area of $6,500 \mathrm{~km}^{2}$, of which $1,800 \mathrm{~km}^{2}$ is in the Czech Republic (Dopita et al. 1997). The Ostrava Formation sequence spans the uppermost Viséan to Serpukhovian (Pendleian and Arnsbergian (Namurian A)) and reaches a thickness of $1,500 \mathrm{~m}$ in the northwest, with more than $3,200 \mathrm{~m}$ of siliciclastic sedimentary rocks and coals in the depocenter (Kumpera and Martinec 1995). Fully continental coal-bearing deposits of Bashkirian age (Marsdenian Langsettian, Namurian B - Westphalian A; Tab. 1) attain a thicknesses $>1,000 \mathrm{~m}$ (Karviná Formation; Kumpera and Martinec 1995). Pennsylvanian coal-bearing intervals overlie the fining-upward sequences of coarse-clastic fluvial regimes which, in turn, are truncated by fluvial incision (Gastaldo et al. 2009). The Karviná Formation is divided into Saddle, Suchá and Doubrava members (Tab. 1).

The Saddle Member is $180-270 \mathrm{~m}$ thick and starts with seam No. 504 (Prokop). This unit is characterized by the prevalence of sandstones and conglomerates, mudstones are 
less represented. 27 coal seams are developed from which three to eleven are mineable (Dopita et al. 1997). This unit represents the middle part of the Upper Namurian strata (Marsdenian and part of the Yeadonian; Tab. 1).

The base of the Suchá Member is positioned at floor level of seam No. 605 (33) (Tab. 1). The freshwater faunal Hubert Horizon above coal seam No. 25 divides the Suchá Member into lower and upper parts. The Namurian/Westphalian boundary is beneath coal seam No. 27 (Purkyňová 1963, 1996, Havlena 1964) with the first appearance of the index species Lyginopteris hoeningshausii (Tab. 1). The thickness of the Lower Suchá Member varies from 178 to $265 \mathrm{~m}$ and in the Upper Suchá Member from 107 to $160 \mathrm{~m}$ with a predominance of siltstones and claystones (Dopita et al. 1997). In the Lower and Upper Suchá members, a total of 48 coal seams have been identified, of which 23 are mineable.

The base of the Doubrava Member is placed at the floor level of coal seam No. 16 (Dopita et al. 1997; Tab. 1). The upper boundary is erosional. In the Karviná area, this unit is $600 \mathrm{~m}$ thick (it also contains the so called Upper Doubrava Member with one mineable coal seam). 34 basic cycles comprised mainly of siltstones and claystones. The Doubrava Member is a product of sedimentation which took place in a lake-alluvial environment with meandering rivers, resulting in many thin seams (76-86) that are mostly not exploitable.

\section{Systematic palaeobotany}

\section{Order Cordaitales CAMPB., 1902 (Cordaitanthales S.V.MeYEn, 1984)}

\section{Genus Cordaites Unger, 1850}

\section{Cordaites karvinensis ŠIMŮNEK, 2007}

P1. 1, Figs 1-7, P1. 2, Figs 1-7, P1. 3, Fig. 1

2000 "Cordaites principalis"; Šimůnek, p. 27, fig. 2:1, 2.

2001 Cordaites "principalis" (Gemar) GeINITZ (morfotyp 1 sensu Šimůnek 2000); Šimůnek, pp. 32-34, fig. 15a-e, pl. 2, fig. 1, pl. 4, figs 1-4.

2001 Cordaites "principalis" (Gemar) GeInItz (morfotyp 2 sensu Šimůnek 2000); Šimůnek, pp. 34-36, fig. 16a-g, pl. 2, fig. 2, pl. 4, figs 5-9, pl. 5, figs 1-3.

2007 Cordaites karvinensis ŠImŮNeK, p. 108, text-fig. 10a-e, pl. 2, fig. 1, pl. 4, figs 1-4.

2007 Cordaites sustae ŠIMŮNEK, p. 109, text-fig. 11a-g, pl. 2, fig. 2, pl. 4, figs 5-9, pl. 5, figs 1-3.

Holoty pe. Inv. no. A 5999, coll. Ostrava Museum (Šimůnek 2007: text-fig. 10a-e, pl. 2, fig. 1, pl. 4, figs 1-4).

Type locality. Karviná, Hlubina Mine, Upper Silesian Basin, the Czech Republic.

Type horizon. Karviná Formation, Upper Suchá Member, Coal seam No. 19, Langsettian (Westphalian A).

Additional material. Inv. no. A 6581, coll. V. Šusta, Ostrava Museum (holotype of Cordaites sustae; Šimůnek 2007: text-fig. 11a-g, pl. 2, fig. 2, pl. 4, figs 5-9, pl. 5, figs 1-3).

Emended diagnosis. Haplocheilic, relatively narrow, lanceolate hypostomatic leaves with medium-dense parallel venation and bluntly pointed apex. 1 or 2 thin veins (sclerotic bundles) alternate with each thick (true) vein. Adaxial cuticle with oblong to trapezoidal cells. Cells of the abaxial cuticle are papillary, tetragonal, stomata dispersed in more or less poorly defined, rare stomatal rows. Guard cells surrounded by proximal papillae more or less joined at the base. Polar ends of the guard cells form a swallow-tail extension.

$\mathrm{D}$ e s c r i p t i o $\mathrm{n}$. The holotype is a fragment of a leaf(A 5999) $205 \mathrm{~mm}$ long and $20 \mathrm{~mm}$ wide. The specimen A 6581 is $180 \mathrm{~mm}$ long and $28 \mathrm{~mm}$ wide. The venation is parallel. There are 34 veins per $\mathrm{cm}$ at the leaf margin, and 38 veins per $\mathrm{cm}$ in the middle of the leaf (Pl. 1, Fig. 3). One to two thin veins (sclerotic bundles) alternate with each thick (true) vein. The leaves are hypostomatic. (Only one putative stoma was observed on the adaxial cuticle; see Pl. 3, Fig. 1).

Adaxial cuticle (Pl. 1, Fig. 4, Pl. 2, Fig. 7, Pl. 3, Fig. 1): The ordinary cells are differentiated into costal and intercostal areas. Bands formed by relatively narrow cells (15-20 $\mu \mathrm{m})$ alternate with bands consisting of cells 20-30 $\mu \mathrm{m}$ wide (Pl. 3, Fig. 1). The cells are markedly elongate, 40 $100 \mu \mathrm{m}$ long, usually of oblong or trapezoidal shape. The anticlinal walls are straight. The cells are oriented parallel to the veins.

Abaxial cuticle (Pl. 2, Figs 3-6): The ordinary cells are not differentiated into costal and intercostal fields. Stomata are arranged in poorly defined stomatal rows. The cells are papillate, elongated, of tetragonal (oblong) shape. The ordinary cells among the stomata are 35-60 $\mu \mathrm{m}$ long and 15-20 $\mu \mathrm{m}$ wide. At certain intervals, unicellular rows of elongated cells occur. These cells are 100-200 $\mu \mathrm{m}$ long and about $15 \mu \mathrm{m}$ wide. The anticlinal walls are \pm straight. The cells and stomatal complexes are oriented parallel to the veins. The guard cells are of crescent shape, 40-55 $\mu \mathrm{m}$ long (including their swallow-tail elongation) and 5-8 $\mu \mathrm{m}$ wide (P1. 2, Fig. 6). They are usually surrounded by 2 polar and 2 lateral subsidiary cells of the same shape as the ordinary epidermal cells, i.e. oblong. The stomatal pore is surrounded by proximal papillae growing from the subsidiary cells. The stomatal density is $170-190$ stomata per $\mathrm{mm}^{2}$ (sample A 5999) and only 89-143 stomata per $\mathrm{mm}^{2}$ in the case of sample A 6581. The stomatal index could be calculated only for this sample: $\mathrm{SI}=13.3-17$.

D i s c u s s i o n. The leaves and venation of the species Cordaites karvinensis belong to narrow-leaved forms. Cordaites karvinensis and C. sustae were distinguished by slightly different venation pattern. However, it can be caused by taphonomical processes. The adaxial cuticle in both specimens representing holotypes of $C$. karvinensis and $C$. sustae is practically identical. The reason why the two species were separated was due to differences in their abaxial cuticles. However, it seems that these are caused by differences in preservation. Cuticles of Cordaites karvinensis were poorly preserved with dirt on the abaxial surface, poorly visible anticlinal walls which were dashed in Šimůnek's (2007) drawing. During the new observation, it was recognized that the small piece of dirt is a papilla in reality and in some guard cells the same swallow-tail polar endings were distinguished as in the holotype of C. sustae. In addition, because both taxa come from the same locality 
and the same stratigraphy - roof of the coal seam 19, it is very probable that the two earlier recognized species belong to one species. Now, the correct name should be Cordaites karvinensis.

\section{Comparison with dispersed cuticles}

Only two dispersed cordaitalean species are similar to the abaxial cuticle Cordaites karvinensis. They are Cordaabaxicutis jaworznoensis ŠIMƯNEK et FLORJAN from the Jaworzno Locality in Poland (Šimůnek and Florjan 2013a, b) and Cordaabaxicutis cf. jaworznoensis from Karviná, ČSA Mine (Šimůnek 2019). The genus Cordabaxicutis was erected for dispersed cordaitalean cuticles which could not be classified as Cordaites species.

The stomatal complexes of all these species are practically identical, even the swallow-tail polar projection of guard cells is present in each of them. However, there are also differences. C.jaworznoensis has short polar subsidiary cells and stomata arranged in either single or double stomatal rows (Pl. 3, Figs 2, 3). This feature distinguishes $C$.jaworznoensis from all the above-mentioned species. Cordaites karvinensis has stomata dispersed in the lamina surface, forming poorly defined sparse stomatal rows. Possible costal area cells do not differ from the other ordinary cells of the epidermis. Cordaabaxicutis cf. jaworznoensis from Karviná has stomata arranged in wide stomatiferous bands (Pl. 3, Figs 4-7), separated by very narrow non-stomatiferous (costal) bands that are formed of cells having the same shape as the ordinary cells, but lighter than the other cells ( $\mathrm{Pl} .3$, Figs 4,5$)$. The stomata within the stomatiferous band are arranged in poorly defined stomatal rows, similarly as in Cordaites karvinensis. C. karvinensis specimen A 5999, which has poorly preserved cuticles, has a stomatal density $(\mathrm{SD})=170-190$ stomata per $\mathrm{mm}^{2}$. It was not possible to state a stomatal index (SI). The $C$. karvinensis specimen A 6581 has a lower SD: $89-143$ stomata per $\mathrm{mm}^{2}$ and SI =13.3-17. This SI is similar to that in Cordaabxicutis cf. jaworznoensis: SI = 13.2-16.8 (Šimůnek 2019), however, the SD is higher: $173-236$ stomata per $\mathrm{mm}^{2}$. It is remarkable that the SI is almost identical in Cordaites karvinensis and Cordaabaxicutis cf. jaworznoensis. C. cf. jaworznoensis has a higher stomatal density which is caused by the smaller sized cells and guard cells. Its guard cells are 17-22 $\mu \mathrm{m}$ long, whereas the guard cells of Cordaites karvinensis are 30-35 $\mu \mathrm{m}$ long (excluding the swallow-tail projections). $C$. jaworznoensis from Poland has guard cells comparable with those in $C$. cf. jaworznoensis from Karviná, however, it has very small polar subsidiary cells and generally smaller cells, therefore the stomatal density is $440-490$ stomata per $\mathrm{mm}^{2}$ (new measurement) and the SI is 19.6-21.9.

All these species come from different stratigraphical levels. The oldest is Cordaabaxicutis cf. jaworznoensis from Karviná (Šimůnek 2019), from Lower Suchá Member, near the Namurian/Westphalian Boundary (see Tab. 1; ca. 319 Ma, Gradstein et al. 2012). Cordaites karvinensis comes from Karviná, Upper Suchá Member, which is a little younger part of the lower Langsettian, indicating an age of around $318.8 \mathrm{Ma}$. Cordaabaxicutis jaworznoensis from Poland (Šimůnek and Florjan 2013a, b) comes from Orzesze
Beds, approximately in the middle of the Duckmantian, ca. 316 MA. There is a short interval between Cordaabaxicutis cf. jaworznoensis and Cordaites karvinensis and any differences in cuticles are not significant, whereas the time interval between these species and Cordaabaxicutis jaworznoensis from Poland is nearly $3 \mathrm{Ma}$ and this species differs in its smaller cells and guard cells and in forming stomatal rows. Possibly all these species could represent one evolutionary line.

\section{Other representatives in the assemblage}

Decades of work carried out by E. Purkyňová aimed at identifying plant fossils from boreholes in the area were summarised in an unpublished report (Šimůnek et al. 1998). R. Gastaldo (in Šimůnek et al. 1998) defined "genetic" cycles for the Ostrava and Karviná formations and he combined the cycles of coal seams 19 and 20 into one "genetic" cycle. We did not take into account the frequency of individual species, but the floral list is relatively poor in comparison with other cycles. The following species have been identified: Lepidodendron sp., Sigillaria voltzii Brongn., Lepidostrobus variabilis Lindu. et HutTon, Calamites cistii Brongn., C. schuetzeiformis KIDST. et Jongm., C. suckowii Brongn., Asterophyllites charaeformis (Sternb.) Göpp., A. longifolius (Sternb.) Brongn., Annularia radiata (Brongn.) Sternb., Sphenophyllum cuneifolium (Sternb.) Zeiller, Alloiopteris angustissima (StERnB.) H.Potonié, Pecopteris miltonii (Artis) Brongn., P. ophiodermatica (Göpr.) Schimp., Senftenbergia plumosa (ARTIS) Brongn., Diplotmema geniculatum (GERmar et KAULF.) Stur, Sphenopteris flexuosisima Stur, S. frenzlii (StUr) ZeILler, S. (Renaultia) schatzlarensis (STUR) ZEILlER, Karinopteris acuta (BRONGN.) Boersma, Mariopteris muricata (Schloth.) ZeIller, Alethopteris urophylla (BRONGN.) GöPP., Neuralethopteris schlehanii (STUR) LAVEIne, Paripteris gigantea (STERnB.) Gothan, Ginkgophyllum delvalii (CAMBIER et Renier) HøEG, Cordaites palmaeformis (GöPP.) WeIss and C. principalis (Germar) Geinitz. Susta's collection in the Ostrava Museum particularly from coal mines is not included because this collection is organised according to the botanical system and selection according to coal seams would be very difficult. Šusta (1928) mentioned only lists of flora for the whole members.

\section{Reconstruction of the habitat}

Mudstones from the roof of coal seam 19 are the product of a wet tropical climate. However, arborescent lycopsids are not a dominant group in the mudstone. It is the same situation as in coal seam 26 (Šimůnek 2019). Ferns are also flood basin habitat dwellers, including peat swamps (Behrensmeyer et al. 1992). Sphenopsids (Calamites, Sphenophyllum) also grew in wet parts of the flood basin and in high-energy aggradational environments. Pteridosperms, that dominated in the assemblage prefered better-drained parts of flood basins or nutrient-rich parts of swamps (Behrensmeyer et al. 1992). Different species of cordaitaleans were adapted to peat or mineral substrate swamps. Ginkgophyllum delvalii probably had similar 
ecological demands as cordaitaleans because it is also a gymnospermous plant of similar habit.

Cuticles from cordaitaleans of dry habitats are not known because the embedding rocks usually prevent their preservation. However, cuticles of "in situ" cordaitaleans and dispersed cuticles from coal are known. Šimůnek (2007) published many species of "in situ" cordaitaleans from different types of rocks (roof mudstones or tuffaceous intercalations) and most of them did not have any papillae. The exception discussed here was Cordaites karvinensis. Wartmann (1969) published a cordaitalean cuticle isolated from coal and it had many papillae on the abaxial side. He studied these papillae and came to the conclusion, that they were not "true" papillae because they did not originate from a specialised cell and additionally they were not hollow but were only cutin thickenings on ordinary cells. Maybe these papillae are not epidermal papillae, but are cuticular papillae. When we described dispersed cuticles from the Polish part of the Upper Silesian Basin (Šimůnek and Florjan 2013b), we ascertained that most of the abaxial cordaitalean cuticles have these papillae. We do not know exactly why they have this adaptation, but it is probably an adaptation to a wet climate, because an uneven surface on the abaxial cuticle could accelerate water flow from the abaxial leaf surface and thus enable enhanced transpiration as the water drops could not obstruct the stomatal pore. This is in concordance with Cleal and Shute (2012).

From the above mentioned points, it appears that the climate was relatively wet because the adaxial cuticle of Cordaites karvinensis has many such papillae. It is comparable to the dispersed Cordaabaxicutis cf. jaworznoensis from Karviná and C. jaworznoensis from Poland. It is unexpected that Cordaites karvinensis has a lower stomatal density than both the above mentioned Cordaabaxicutis species, however, it does have bigger stomata. All these species come from different stratigraphic levels. The implication of stomatal density in these species on $\mathrm{CO}_{2}$ concentration in the palaeoatmosphere has not yet been studied.

\section{Conclusions}

1. Cordaites karvinensis Š IMU゚NEK, 2007 and C. sustae ŠIMŮNEK, 2007 are considered here as conspecific, with Cordaites karvinensis ŠIMŮNEK, 2007 chosen here as a correct name.

2. Abaxial cuticle of Cordaites karvinensis resembles that of the Polish Cordaabaxicutis jaworznoensis from the Orzesze Beds and the Bohemian Cordaabaxicutis cf. jaworznoensis from the Lower Suchá Member. All these species have solid papillae on cells of the abaxial cuticle.

3. The presence of solid papillae on the abaxial cuticle may help water removal from the abaxial leaf surface and prevent water drops occupying the stomatal pores and thus enabling better transpiration.

4. The above mentioned species may represent one evolutionary lineage, however their classification is not resolved here.

5. The climate was probably tropical, wet and humid.

\section{Acknowledgements}

The author wishes to thank both reviewers, C. J. Cleal from Cardiff (Great Britain) and S. V. Naugol'nykh from Moscow (Russia), for their comments. This work was financially supported by internal project CGS 323100.

\section{References}

Behrensmeyer, A. K., Damuth, J. D., DiMichele, W. A., Potts, R., Sues, H.-D., Scott, L. W. (1992): Terrestrial ecosystems through time. - The University of Chicago Press, Chicago, 568 pp.

Cleal, C. J., Opluštil, S., Thomas, B. A., Tenchov, Y., Abbink, O. A., Bek, J., Dimitrova, T., Drábková, J., Hardkopf-Fröder, C., van Hoof, T., Kedzior, A., Jarzembowski, E., Jasper, K., Libertín, M., McLean, D., Oliwkiewicz-Miklasinska, M., Pšenička, J., Ptak, B., Schneider, J. W., Schultka, S., Šimůnek, Z., Uhl, D., Waksmundzka, M. I., van Waveren, I., Zodrow, E. L. (2009): Late Moscovian terrestrial biotas and palaeoenvironments of Variscan Euramerica. - Netherlands Journal of Geosciences - Geologie en Mijnbouw, 88(4), 181-278. https://doi.org/10.1017/S0016774600000846

Cleal, C. J., Shute, C. H. (2012): The systematic and palaeontological value of foliage anatomy in Late Palaeozoic medullosalean seed-plants. - Journal of Systematic Palaeontology, 10: 765-800. https://doi.org/10.1080/14772019.2011.634442

Dopita, M., Aust, J., Brieda, J., Černý, I., Dvořák, P., Fialová, V., Foldyna, J., Grmela, A., Grygar, R., Hoch, I., Honěk, J., Kaštovský, V., Konečný, P., Kožušníková, A., Krejčí, B., Kumpera, O., Martinec, P., Merenda, M., Müller, K., Novotná, E., Ptáček, J., Purkyňová, E., Řehoř, F., Strakoš, Z., Tomis, L., Tomšík, J., Valterová, P., Vašíček, Z., Vencl, J., Žídková, S. (1997): Geologie české části hornoslezské pánve [Geology of the Czech part of the Upper Silesian Basin]. - Ministerstvo životního prostředí České republiky [Ministry of the Environment of the Czech Republic], Praha, 280 pp. (in Czech with English summary)

Gastaldo, R. A., Purkyňová, E., Šimůnek, Z., Schmitz, M. D. (2009): Ecological persistence in the Late Mississippian (Serpukhovian, Namurian A) megafloral record of the Upper Silesian Basin, Czech Republic. - PALAIOS, 24: 336-350. https://doi.org/10.2110/palo.2008.p08-084r

Gradstein, F. M., Ogg, J. G., Schmitz, M., Ogg, G. (2012): The Geologic Time Scale 2012. - Elsevier, Amsterdam, Boston, Heidelberg, London, New York, Oxford, Paris, San Diego, San Francisco, Singapore, Sydney, Tokyo, 1176 pp.

Havlena, V. (1964): Geologie uhelných ložisek 2 [Geology of coal deposits]. - Nakladatelství Československé akademie věd, Praha, 437 pp. (in Czech)

Kerp, H. (1990): The study of fossil Gymnosperms by means of cuticular analysis. - PALAIOS, 5: 548-549. https://doi.org/10.2307/3514861

Kumpera, O., Martinec, P. (1995): The development of the Carboniferous accretionary wedge in the Moravian-Sile- 
sian Paleozoic Basin. - Journal of the Czech Geological Society, 40: 47-64.

Purkyňová, E. (1963): Fytostratigrafie moravskoslezského karbonu [Phytostratigraphy of Moravian and Silesian Carboniferous]. - Rozpravy Československé akademie věd, Řada matematicko-př́rodních věd, 73(9): 1-36. (in Czech with German summary)

Purkyňová, E. (1996): Namurian-Westphalian fossil plant taxa and assemblages in the Czech part of the Upper Silesian Coal Basin. - In: Leary, R. L. (ed.), Patterns in Paleobotany: Proceedings of a Czech-U.S. Carboniferous Paleobotany Workshop. Illinois State Museum Scientific Papers, 26: 29-32.

Šimůnek, Z. (2000): Cuticles of Cordaites from the Westphalian, Stephanian and Autunian of the Bohemian Massif (Czech Republic). A preliminary study. - Acta Palaeobotanica, 40(1): 25-34.

Šimůnek, Z. (2001): Kordaity svrchního karbonu a permu Českého masivu (Studium epidermálních struktur) [Upper Carboniferous and Permian cordaitaleans of the Bohemian Massif (epidermal studies)]; Kandidátská disertační práce [CSc. Thesis]. - MS, Český geologický ústav [Czech Geological Survey], Prague, the Czech Republic, 125 pp. +44 pls. (in Czech) (copy in the library of the Depratment of Palaeontology, National Museum, Prague)

Šimůnek, Z. (2007): New Classification of the genus Cordaites from the Carboniferous and Permian of the Bohemian Massif, based on cuticle micromorphology. - Sborník Národního muzea v Praze, řada $\mathrm{B}$ - př́rodní vědy [Acta Mususei Nationalis Pragae, Series B - Historia Naturalis], 62(3-4): 97-210.

Šimůnek, Z. (2019): The earliest evidence of cordaitalean cuticles from coal in the Pennsylvanian of Europe (Langsettian, Upper Silesian Basin, Czech Republic). Review of Palaeobotany and Palynology, 261: 81-94. https://doi.org/10.1016/j.revpalbo.2018.11.007
Šimůnek, Z., Drábková, J., Purkyňová, E., Gastaldo, R. A., Eble, C. F. (1998): Tafonomická charakteristika rostlin a odezva vegetace na klimatické změny v mezihorských karbonských pánvích v České republice - floristická studie hornoslezské pánve [Plant taphonomy and vegetation response to the climatic changes in intermountain basins in the Czech Republic - palaeobotanic studies in Upper Silesian Basin]; Závěrečná zpráva [Final Report] . - MS, Český geologický ústav [Czech Geological Survey], Prague, the Czech Republic, 50 pp. (in Czech) (copy in Archive of the Czech Geological Survey, Prague)

Šimůnek, Z., Florjan, S. (2013a): An artificial system of dispersed cordaitalean cuticles from the Upper Silesian Basin (Pennsylvanian, Poland) and its application to dispersed cordaitalean cuticles from the Intrasudetic Basin (Pennsylvanian, Czech Republic). - Paleobotanicheskiy vremenik (supplement to Lethaea rossica. The Russian Journal of Palaeobotany), 1: 53-65.

Šimůnek, Z., Florjan, S. (2013b): The Pennsylvanian cordaitalean dispersed cuticles from the Upper Silesian Basin (Poland). - Review of Palaeobotany and Palynology, 197: 26-49. https://doi.org/10.1016/j.revpalbo.2013.04.006

Šusta, V. (1928): Stratigrafie ostravsko-karvinské oblasti ve světle paleontologie [Stratigraphy of Ostrava-Karviná coal basin from the palaeontological viewpoint]. - In: Kamenouhelné doly ostravsko-karvinského revíru, I. [Hard coal mines in Ostrava-Karviná Coal District, I.]. Ředitelská konference ostravsko-karvinského kamenouhelného revíru, Moravská Ostrava, pp. 341-429. (in Czech)

Wartmann R. (1969): Studie über die papillen-förmigen Verdickungen auf der Kutikule bei Cordaites an Material aus dem Westphal C des Saar-Karbons. - Argumenta Palaeobotanica, 3: 199-207. 


\section{Explanations to the plates}

\section{PLATE 1}

Cordaites karvinensis ŠIMŮNEK, holotype, Karviná, Hlubina Mine, Upper Suchá Member, roof of coal seam 19. Coll. J. Šusta, Ostrava Museum, Ostrava, inv. no. A 5999

1. A leaf, material to slides $173 / 1-3$.

2. Close up of the venation from Fig. 1.

3. Venation of the macerated leaf.

4. Adaxial cuticle with parallel oriented tetragonal cells. Slide 173/2.

5. Poorly preserved abaxial cuticle with stomata seemingly irregularly dispersed on the surface. Slide 173/2.

6. Close up of stomata in poorly defined rows. Note the papillae. Slide 173/2.

7. Close up of a stoma from Fig. 6.

\section{PLATE 2}

Cordaites karvinensis ŠIMŮNEK, Karviná, Hlubina Mine, Upper Suchá Member, roof of coal seam 19. Coll. J. Šusta, Ostrava Museum, Ostrava, inv. no. A 6581

1. A leaf, material to slides 299/1-2.

2. Close up of the venation from Fig. 1.

3. Stomata dispersed on the surface. Slide 299/1.

4. Abaxial cuticle with stomata. Note papillae surrounding the stomata and papillae on the ordinary cells.

5. Close up of papillae surrounding the stomata and on the ordinary cells from Fig. 4.

6. Detail of a stoma with papillae from Fig. 5.

7. Adaxial cuticle, slide 173/2.

\section{PLATE 3}

Cordaites karvinensis ŠIMUீNEK, Karviná, Hlubina Mine, Upper Suchá Member, roof of coal seam 19. Coll. J. Šusta, Ostrava Museum, Ostrava, inv. no. A 6581

1. Adaxial cuticle, close up from Pl. 2, Fig. 7. Questionable stoma marked with an arrow.

Cordaabaxicutis jaworznoensis S̆IMŮNEK et FLORJAN.

2. Abaxial cuticle with stomatal rows.

3. Close up of stomata from Fig. 2. Note connate papillae around stomata and papillae on the ordinary cells. Loc. Jaworzno, slide 148 .

Cordaabaxicutis cf. jaworznoensis ŠIMU゚NEK et FloRJAN.

4. Abaxial cuticle with stomatiferous bands. Note very narrow non-stomatiferous bands (arrows). Slide 692/2.

5. Close up of cuticle from Fig. 4 with stomatiferous bands and papillae.

6. Close up of a stoma from Fig. 5. Note papillae around the stomatal pore and papillae on the ordinary cells. 
PLATE 1

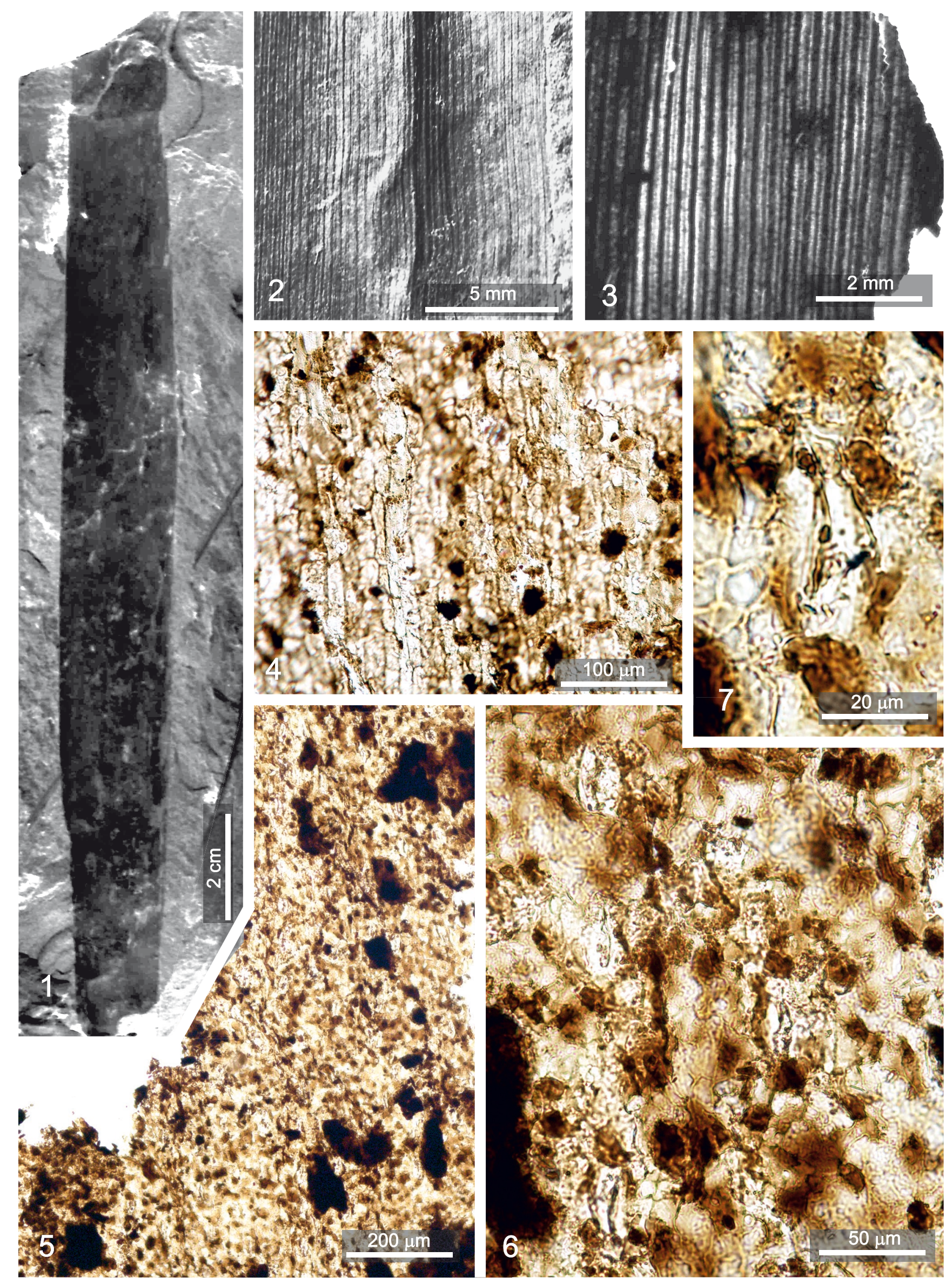


PLATE 2
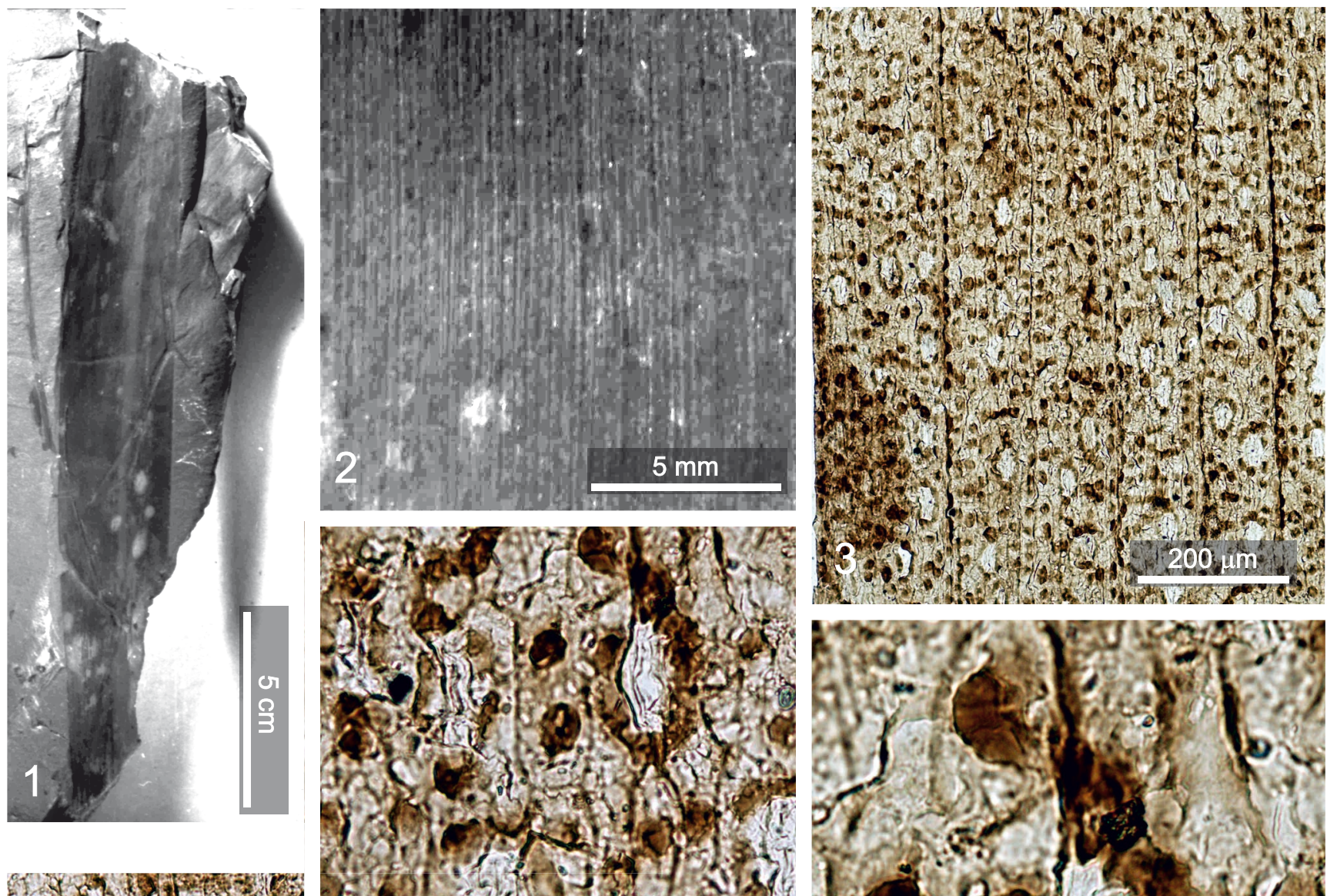

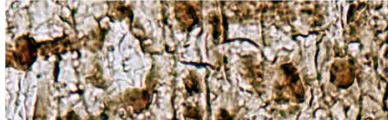

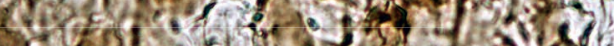
for o f (2) 3. $10 \%$ (

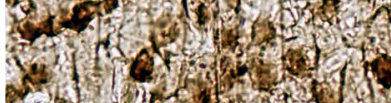
dy 10 -

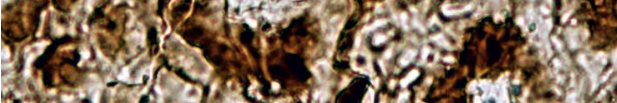

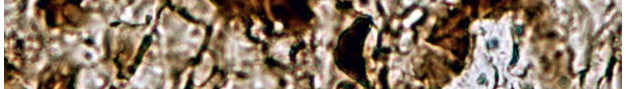

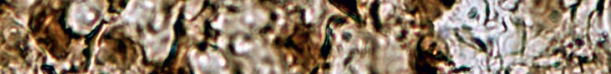

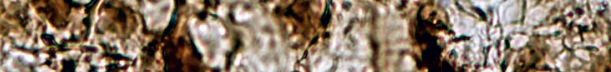
ant. Welolu $x=5$ Wars th in

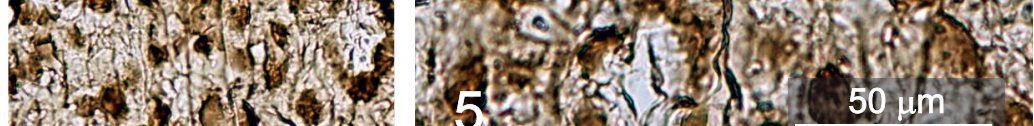

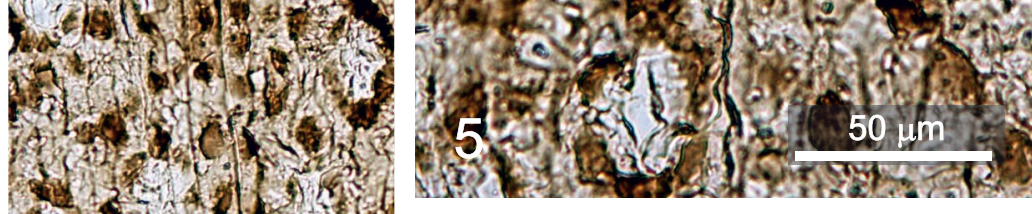

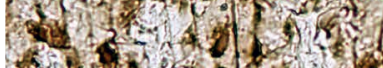
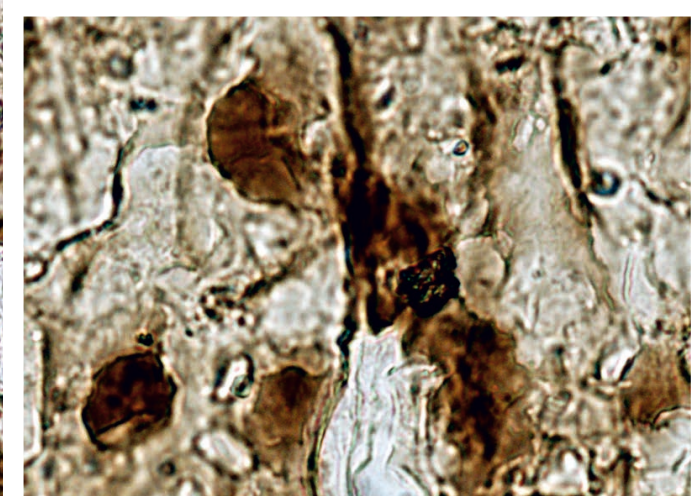

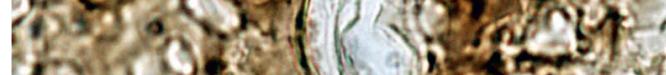
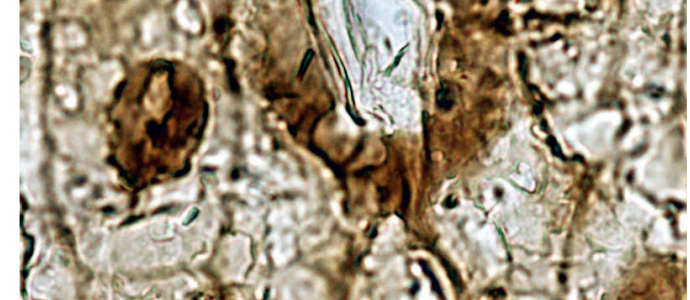

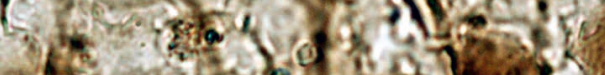

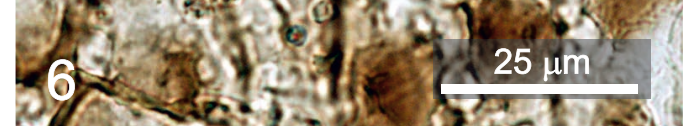

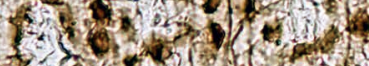

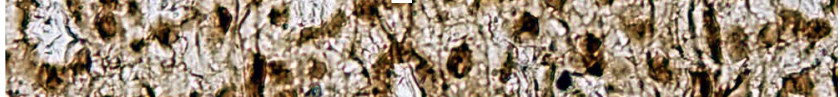


2. (1) (1)

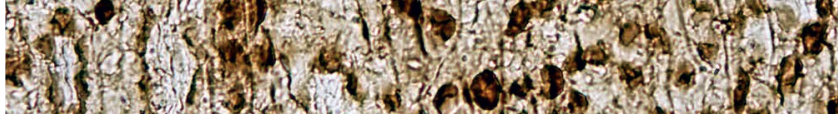



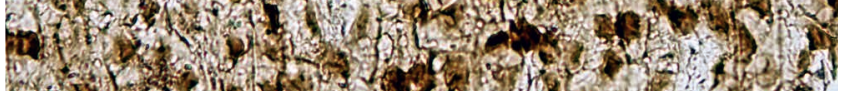

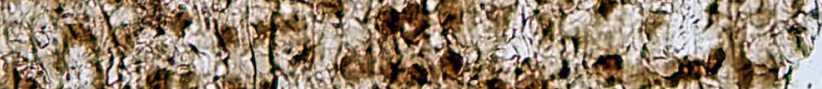
P. 30. 3.

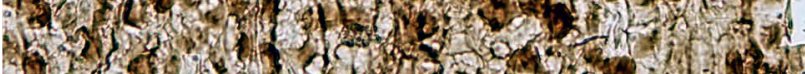

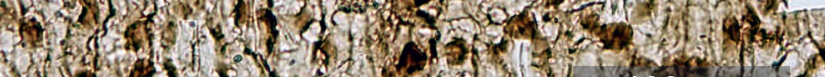

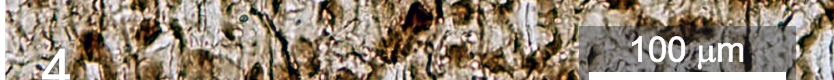

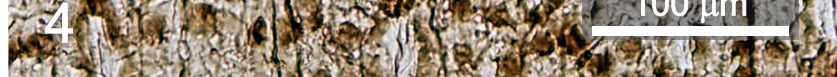

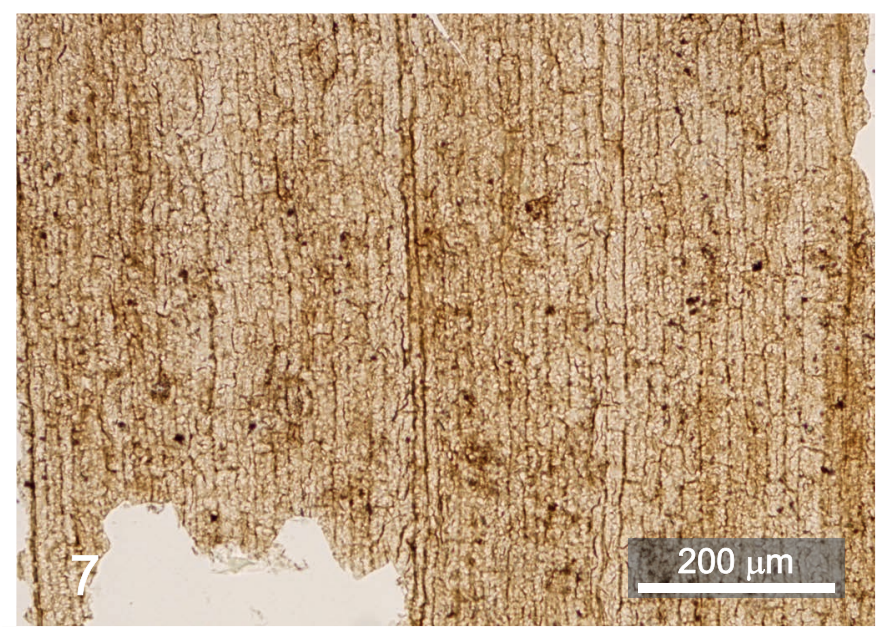


PLATE 3

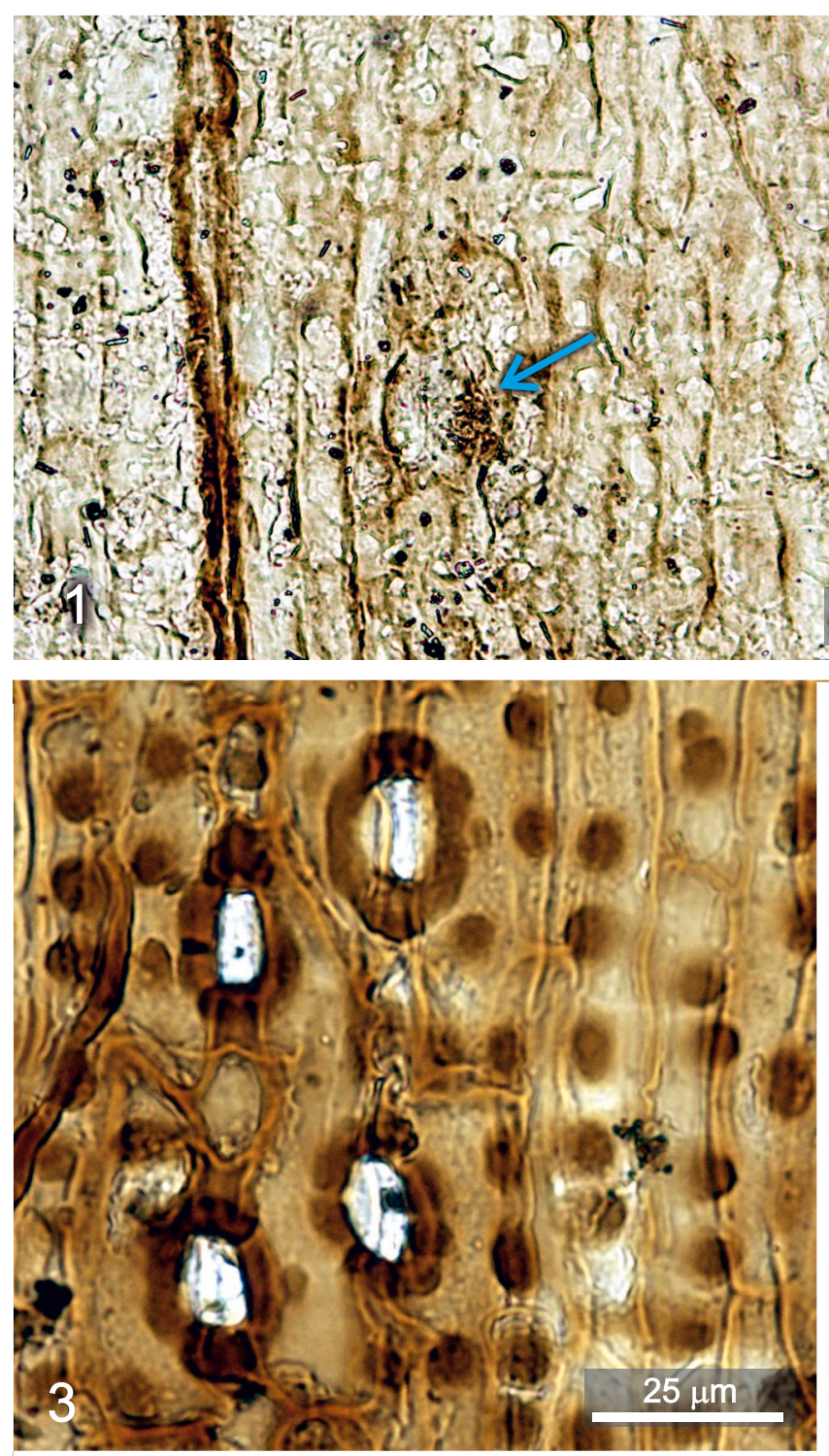

$x^{3} \cdot 1$
